\title{
Increasing Nitrogen Availability at Veraison through Foliar Applications: Implications for Leaf Assimilation and Fruit Ripening under Source Limitation in 'Chardonnay' (Vitis vinifera L.) Grapevines
}

\author{
Letizia Tozzini, Paolo Sabbatini ${ }^{1}$, and G. Stanley Howell \\ Department of Horticulture, Michigan State University, Plant and Soil \\ Science Building, East Lansing, MI 48824
}

Additional index words. Vitis vinifera, source sink, fruit set, fruit quality and composition, yeast available nitrogen (YAN), photosynthesis, foliar fertilizer

\begin{abstract}
Viticulture in Michigan is often limited by cool and humid climate conditions that impact vine growth and the achievement of adequate fruit quality at harvest. Sugars, pH, acids, and yeast available nitrogen (YAN) are indices of quality and, as such, of suitability for wine production. The aim of this study was to evaluate the efficacy of foliar nitrogen $(N)$ fertilization applied as a $1 \% \mathrm{w} / \mathrm{v}$ urea solution at veraison as a method to increase canopy $\mathbf{N}$ availability during the fruit ripening stage. To test the effect on different source sink conditions, we imposed three levels of defoliation $(0 \%, 33 \%$, and $66 \%$ of leaves removed per vine) and measured net photosynthetic rate $\left(P_{n}\right)$, leaf efficiency parameters, yield components, and fruit quality parameters. Apical leaf $P_{n}$ was increased by the $33 \%$ defoliation $(+12 \%$ from the undefoliated control) and by the urea application $(+6 \%) 2$ weeks after veraison. In basal leaves we observed a reduction in chlorophyll content (SPAD) and maximum photochemical efficiency of PSII $\left(F_{v} / F_{m}\right)$ as a result of the defoliation treatment and secondarily by the $\mathbf{N}$ application, which resulted in a reduction in $P_{n}$. Therefore, mean shoot $P_{n}$ was unaffected by the treatments. Although neither main nor lateral shoot growth was increased by any defoliation treatment, both percent soluble solids $(\% \mathrm{SS})$ and berry weight were significantly reduced by the $66 \%$ defoliation treatment. Application of urea increased yeast available amino acids by $20 \%$ but did not impact \%SS or other chemical parameters indicating a different accumulation pathway for sugars and amino acids in the berry.
\end{abstract}

Nitrogen is quantitatively the most important mineral nutrient for grapevine growth and reproduction (Keller, 2010) and its use as a fertilizer impacts canopy efficiency and fruit growth and maturation (Jackson and Lombard, 1993). During canopy development, adequate $\mathrm{N}$ supply is used in the leaves to maintain high levels of chlorophyll and proteins, like Rubisco, inside the chloroplasts. $\mathrm{N}$ availability is correlated with the net $\mathrm{P}_{\mathrm{n}}$ of the canopy (Keller, 2005). Importantly, leaves are not the exclusive sink for mineral $\mathrm{N}$,

\footnotetext{
Received for publication 29 Nov. 2012. Accepted for publication 24 Mar. 2013.

This research was partially supported by AgBioResearch at Michigan State University (Project GREEEN), the Michigan Grape and Wine Industry Council, and the MSU Southwest Michigan Research and Extension Center.

We appreciate the assistance of P. Murad, D. Acimovic, and S. Zhuang in collecting data; of D. Francis for his help in vineyard maintenance; and of A. Green for critical reading of the manuscript.

${ }^{1}$ To whom reprint request should be addressed; e-mailsabbatin@msu.edu.
}

because it is partitioned among different vine organs at different stages of grapevine development (Conradie, 1990). The total content of berry $\mathrm{N}$ increases linearly through the full cycle of berry growth. However, the accumulation of total free amino acid in the berries increases at the onset of veraison and contributes to the pool of YAN, which includes $\mathrm{N}$ in the form of $\alpha$-amino acids and ammonia (Bell and Henschke, 2008). This latter accumulation pattern is quite variable across different grape cultivars (Kliewer, 1968; Rodriguez-Lovelle and Gaudillère, 2002). A low level of YAN in grape must frequently occur in grape cultivars grown under cool climate conditions (Löhnertz et al., 1998) and it is often associated with sluggish-stuck fermentations (Spayd et al., 1995). Low YAN can also lead to the production of off-flavors in wine (Bell and Henschke, 2008).

Aside from nutrient availability, the $\mathrm{P}_{\mathrm{n}}$ of the canopy through the growing season is tied to the vine's sink demand for carbohydrates, driven by both vegetative and reproductive growth. Therefore, manipulation of the source sink ratio can affect grapevine $\mathrm{P}_{\mathrm{n}}$ (Edson et al., 1993). A reduced leaf area or a reduced ratio between leaf area and sink, i.e., cluster numbers or size, have resulted in higher rates of $\mathrm{P}_{\mathrm{n}}$ (Hunter and Visser, 1988; Palliotti et al., 2011; Poni et al., 2008). Although an increase of photosynthesis can compensate for the loss of source availability during fruit development and ripening (Candolfi-Vasconcelos and Koblet, 1991), a compensatory effect can also result from a change in the aging process of the leaves. Older leaves of the canopy, generally corresponding to leaves in the fruit zone, decrease their $P_{n}$ after they reach full development (Poni et al., 1994). It has been observed that older leaves can maintain a higher $\mathrm{P}_{\mathrm{n}}$ when a source reduction is imposed (Petrie et al., 2000b). Because cluster demand for photosynthates varies among different stages of development, the response to defoliation can also vary according to phenological stage. For example, an increase in photosynthesis at veraison, independent of sink size, was also observed (Petrie et al., 2003).

The objective of this study was to determine the effect of foliar applied $\mathrm{N}$ at veraison in relation to source limitation imposed during fruit maturation. In particular, the hypotheses of our study were: $\mathrm{N}$ applied at veraison 1) influences vine performance (yield, fruit chemistry composition, and vine productivity); 2) impacts $P_{n}$ and the leaf aging process; and 3 ) influences $\mathrm{N}$ content of the berries in the form of yeast available amino-N.

\section{Materials and Methods}

Vineyard site. The experiment was conducted in 2011 at Michigan State University's Southwest Michigan Research and Extension Center in Benton Harbor, MI (lat. $42^{\circ} 05^{\prime} 10.55^{\prime \prime} \mathrm{N}$, long. $\left.86^{\circ} 21^{\prime} 03.68^{\prime \prime} \mathrm{W}\right)$. Michigan's climate is characterized by a short growing season (145 to $175 \mathrm{~d}$ ) with cool climate summer conditions $[1200 \pm 300$ growing degree days (GDD)] calculated beginning 1 Apr. through 31 Oct. using the base $10^{\circ} \mathrm{C}$ standard. Climatological data were recorded during the experiment by an automated weather station of the Michigan Automated Weather Network located $200 \mathrm{~m}$ from the experimental vineyards (Fig. 1). The 2011 growing season was characterized by 1485 GDD (Baskerville and Emin, 1969) until the end of September, a warm season when compared with Michigan's average annual GDD accumulation $(1200 \pm 300)$ (Howell and Sabbatini, 2008). Precipitation in the amount of $545 \mathrm{~mm}$ was uniformly spread through the season, showing the classical rainy events in the spring $[\approx 100$ to 120 day of the year (DOY)] and at harvest ( $\approx 240$ to 270 DOY) characteristic of cool climate viticulture in the Great Lakes region of the United States.

Plant material. 'Chardonnay' grapevines (clone Colmar) were planted in 1990 in a Spinks loamy fine soil (U.S. Department of Agriculture, Soil Conservation Service, 1957), grafted on $\mathrm{C} 3309$ rootstock, with spacing of $1.8 \mathrm{~m}$ in the row $\times 2.7 \mathrm{~m}$ between rows with rows oriented north to south. Vines were cane pruned during the winter of 2010 to 35 nodes 


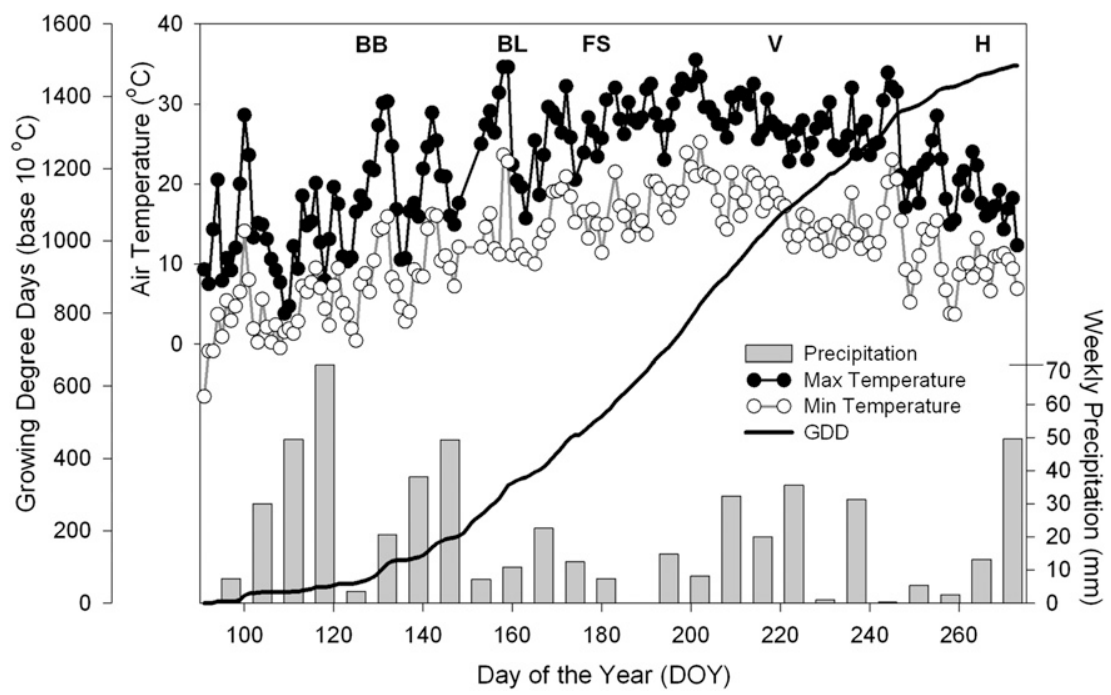

Fig. 1. Seasonal weather conditions (2011) at the experimental vineyard as growing degree-days (GDD) accumulation calculated from 1 Apr. through 30 Sept., minimum and maximum air temperature, and weekly precipitation $(\mathrm{mm})$. Timing of main phenological phases is reported in the graph as bud burst (BB) [13 May or 133 day of the year (DOY)], bloom (BL, 16 June or 167 DOY), fruit set (FS, 27 June or 178 DOY), veraison (V, 12 Aug. or 224 DOY), and harvest (H, 22 Sept. or 265 DOY).

per vine or $\approx 19$ nodes per meter of row and trained to vertical shoot positioning with a fruit-bearing wire $1.2 \mathrm{~m}$ from the ground and there were three sets of catch wires at $40-\mathrm{cm}$ intervals from the fruit-bearing wire. For the 3 years ending with the 2011 growing season, no irrigation or fertilizers were applied to the experimental plot. Soil analysis was performed before bloom and nutrient levels (N: $1.2 \mathrm{~g} \cdot \mathrm{kg}^{-1}$; phosphorus: 154 ppm; potassium: $135 \mathrm{ppm}$; magnesium: $74 \mathrm{ppm}$; calcium: $528 \mathrm{ppm}$ ) were considered sufficient according to vineyard management practices of the eastern United States (Bates and Wolf, 2008; Wise et al., 2008). Clusters per vine were counted 2 weeks after fruit set and clusters thinned to achieve homogeneity of cropping conditions across blocks. Lateral shoots were removed as emerged from the fruiting zone and shoots exceeding the height of the trellis were topped to $30 \mathrm{~cm}$ above the last set of catch wires 2 weeks before veraison.

Treatments and experimental design. The experiment was designed as a randomized complete block with three blocks and these two factors: 1) intensity of defoliation performed at veraison (initial berry softening or Stage 35 as described by Eichhorn and Lorenz, 1977); and 2) application of foliar $\mathrm{N}$ fertilizer. Each combination of the different levels of the two factors was randomly assigned to three vines (replications) within each block. Defoliation was performed manually at three levels: control undefoliated (no leaves removed, "CUD"), 33\% (one leaf every three nodes, "33D"), or $66 \%$ (two leaves every three nodes from each shoot, "66D") of total leaves. Vines designated to be treated with foliar $\mathrm{N}(\mathrm{TN})$ were sprayed with a urea solution $(1 \% \mathrm{w} / \mathrm{v})$ using a backpack sprayer to the whole vine canopy until runoff, whereas control vines $(\mathrm{CN})$ were left unsprayed. Direct spraying of the clusters was avoided.
Because number of leaves and, consequently, leaf area were variable within different defoliation treatments, the total amount of urea per vine varied as well. Based on volume of solution applied on non-defoliated vines $(\mathrm{CUD}+\mathrm{TN})$ of each block, we estimated that $17 \mathrm{~g} \pm 2$ SD of urea was applied on these vines.

Data collection. On each vine, five modal shoots bearing $1.6 \pm 0.2 \mathrm{SD}$ clusters were selected and tagged 2 weeks before veraison. The length of each tagged shoot was measured before treatment application. The number of lateral shoots and their lengths were also recorded. Measurements were repeated 1 week before veraison and 3 weeks after veraison. Total lateral shoot growth was calculated as the sum of lateral length increases from 1 week to 3 weeks after veraison. Leaf area (LA) of the five tagged shoots was estimated using the methodology described by Poni et al. (2008). Random shoots ( $\mathrm{n}=$ 20) from guard vines were collected 2 weeks before veraison and the linear regression between shoot length and total leaf area $(\mathrm{y}=$ $\left.17.04 \mathrm{x}+165.25, R^{2}=0.94\right)$ was calculated and then used to estimate LA per shoot. On defoliated vines (33D and 66D), leaves removed at veraison were collected and LA measured with a LI-3100C area meter (LI-COR, Lincoln, NE). LA at veraison was then calculated as the estimated LA minus the measured LA removed.

Field gas exchange and chlorophyll fluorescence measurements. Single leaf gas exchange measurements were conducted with a CIRAS- 2 portable open system gas analyzer (PP System, Hitchin Herts, U.K.) operated at $0.2 \mathrm{~L} \cdot \mathrm{min}^{-1}$ flow rate, $\mathrm{CO}_{2}$ cuvette concentration of $370 \mathrm{ppm}$, and exposing leaves to natural light levels higher than $1000 \mu \mathrm{mol} \cdot \mathrm{m}^{-2} \cdot \mathrm{s}^{-1}$, above the light saturation level (Kriedemann, 1968). At weekly intervals after the application of treatments, $P_{n}$ was measured on leaves at three different positions: basal nodes 4 and 5 , medial nodes 10 through 15, and apical nodes with fully expanded leaves. Measurements were replicated on three leaves for each position and two vines per each combination of treatments. Measurements were performed at midday (from $1100 \mathrm{HR}$ to $1300 \mathrm{HR}$ ). Shoot mean $P_{n}$ was calculated averaging the measurements from the three different positions. Leaf photosynthetic efficiency was assessed measuring $\mathrm{F}_{\mathrm{v}} / \mathrm{F}_{\mathrm{m}}$ (maximum photochemical efficiency of PSII) on dark-adapted leaves using a portable fluorimeter (HandyPEA; Hansatech Instruments, Kings Lynn, U.K.). Chlorophyll content on leaves is highly correlated with the SPAD index in grapevines (Porro et al., 2001) and, for that reason, we measured leaf chlorophyll using a SPAD meter (Konica Minolta, Osaka, Japan). Measurements were performed on leaves from different nodal positions, 1 and 3 weeks after veraison, following the same sampling procedure used for gas exchange measurements.

Yield components. We harvested the vines $40 \mathrm{~d}$ after veraison (22 Sept. or $265 \mathrm{DOY}$ ) and proceeded to measure yield per vine and count the number of clusters per vine. Tagged shoots (five shoots per vine) were harvested separately; the number of berries per cluster and cluster weights were recorded and mean berry weight calculated. For each cluster, the number of berries showing symptoms of rot (sour rot, black rot, or botrytis) was counted and rot severity was calculated as percent of rot berries per cluster.

Juice analysis. Berries collected from each tagged shoot were frozen $\left(-20^{\circ} \mathrm{C}\right)$, samples were thawed at room temperature for $12 \mathrm{~h}$, and juice expressed from each crushed sample was used for analysis. Juice \%SS was measured using a electronic refractometer (Atago, Kirkland, WA), pH was measured using a 370 Thermo Orion (Beverly, MA) $\mathrm{pH}$ meter, and total titratable acidity (TA, g. $\mathrm{L}^{-1}$ ) was determined using $10 \mathrm{~mL}$ of clear juice in an automatic titrator (Titroline 96, Schott, Germany). Flavor and aroma compounds were also assessed. Total volatile terpenes $\left(\mathrm{mg} \cdot \mathrm{L}^{-1}\right)$ were measured using 40-mL samples from each vine after composition analysis following the procedure described by Iland et al. (2004). Juice primary amino-N concentration was measured by the procedure described by Dukes and Butzke (1998) using a derivatization of primary amino groups assay and a ultraviolet-3600 spectrophotometer (Shimadzu, Kyoto, Japan).

Statistical analysis. Basic statistics, analysis of variance, regression, and correlation analysis were performed using SAS (Version 9.3; SAS Institute Inc., Cary, NC) and Sigma Plot (Version 10; SPSS, Chicago, IL). Results were tested for normality and homogeneity of variance before being subjected to the F-test for determination of the two factors (defoliation and $\mathrm{N}$ application) effects using block as the random effect. When normal distribution criterion was not met, statistical tests were performed on log-transformed results (as reported in results tables). Means 
separation was performed with Fisher's least significant difference test (LSD). When interaction of the two main factors was found significant, all pairwise comparisons between the treatments' means were also conducted with the LSD test. Where parameters were measured by shoot (e.g., fruit chemistry), shoots were used as subsamples within the main experimental unit (vine).

\section{Results}

Canopy growth. The effect of the defoliation treatments on vine canopy is expressed as LA estimates and the three defoliation levels are separated in terms of LA removed and total LA estimated at veraison (Table 1). Length of shoot main axis, measured 3 weeks after the application of treatments, was unaffected by defoliation or by the urea application. Although, after veraison, the rate of shoot growth tends to be slower (data not shown), shoots were still actively growing, especially lateral shoots (Table 1). However, no difference in lateral shoot growth among the different treatments was observed as a consequence of application at veraison. This suggests that neither reducing LA nor increasing $\mathrm{N}$ availability, at the applied levels, had a significant impact on vine growth.

Yield components and juice chemistry. Yield was neither affected by the defoliation treatments nor by the application of foliar urea (Table 2). Because the number of clusters per vine was adjusted after fruit set, no significant yield differences were measured among vines at harvest. Although yield appeared to be unaffected by treatments, we observed a significant reduction in cluster weight ( $9 \%$ from CUD), explained largely by a reduction in berry size $(7 \%)$. This decrease in cluster weight, however, was not the result of a reduction in berry number, which was unaffected by the main factors and only differed from those of the CUD vines at the 66D level. Also noteworthy, cluster size and mean berry weight had intermediate mean values at the 33D treatment level when compared with CUD and 66D. Not surprisingly, leaf removal significantly reduced the severity of cluster rot at harvest (expressed as percentage of berries with rot complex symptoms; Table 2) as reported extensively in the literature (Zoecklein et al., 1992). Moreover, foliar application of urea did not affect cluster rot complex.

Defoliation also affected fruit composition (Table 3). When vines were defoliated to leave only one-third of the leaves at veraison (66D), \%SS was significantly lower than the CUD treatment. Combining the reduction of cluster weight and the reduced \%SS (in 66D), we observed a decrease in shoot productivity, expressed as sugar per shoot (Table 3 ). However, the fruit ripening process was otherwise not influenced, because there were no differences in $\mathrm{pH}$ and $\mathrm{TA}$ or a quality index, like total volatile terpenes, as a result of treatments.

Although basic quality parameters were unaffected by the $\mathrm{N}$ application, $\mathrm{N}$ content of the berries, expressed as free primary
Table 1. Effects of defoliation and nitrogen application on shoot leaf area (LA) and vegetative growth.

\begin{tabular}{|c|c|c|c|c|}
\hline Treatments & $\begin{array}{c}\text { Shoot LA } \\
\text { removed }\left(\mathrm{cm}^{2}\right)\end{array}$ & $\begin{array}{c}\text { Shoot LA at } \\
\text { veraison }\left(\mathrm{cm}^{2}\right)\end{array}$ & $\begin{array}{c}\text { Shoot } \\
\text { Length }(\mathrm{cm})^{\mathrm{y}}\end{array}$ & $\begin{array}{l}\text { Lateral shoot } \\
\text { growth }(\mathrm{cm})^{\mathrm{x}}\end{array}$ \\
\hline \multicolumn{5}{|c|}{ Defoliation (D) } \\
\hline CUD & $0 \mathrm{c}^{\mathrm{w}}$ & $3295 \mathrm{a}$ & 180 & 18 \\
\hline 33D & $1370 \mathrm{~b}$ & $2073 \mathrm{~b}$ & 189 & 23 \\
\hline $66 \mathrm{D}$ & $2430 \mathrm{a}$ & $840 \mathrm{c}$ & 178 & 20 \\
\hline \multicolumn{5}{|l|}{ Nitrogen $(\mathrm{N})$} \\
\hline TN & 1905 & 2092 & 187 & 22 \\
\hline $\mathrm{CN}$ & 1891 & 2016 & 182 & 19 \\
\hline \multicolumn{5}{|l|}{ Significance $^{v}$} \\
\hline $\mathrm{D}$ & $* * *$ & $* * *$ & NS & NS \\
\hline $\mathrm{N}$ & NS & NS & NS & NS \\
\hline $\mathrm{D} \times \mathrm{N}$ & NS & NS & NS & NS \\
\hline
\end{tabular}

${ }^{2}$ Defoliation CUD, 33D, 66D indicate treatments in which 0, one-third, or two-thirds of leaves were removed at veraison, respectively. TN indicates a $1 \%$ urea solution was sprayed at veraison; $\mathrm{CN}$ indicates no urea was applied.

${ }^{y}$ Main axis shoot length measured $20 \mathrm{~d}$ after application of treatments.

xLength of lateral shoot was calculated as the sum of lengths of all laterals present on each shoot 1 and 3 weeks after veraison. Growth is calculated as the increase in length in the time period considered.

${ }^{\text {w}}$ Means in a column followed by the same letter are not significantly different at $P \leq 0.05$ by least significant difference test.

'Result of analysis of variance: *,**,***, and Ns indicate significance at $P \leq 0.05,0.01,0.001$, and nonsignificant, respectively.

Table 2. Impact of defoliation and foliar nitrogen application on yield components.

\begin{tabular}{|c|c|c|c|c|c|c|}
\hline Treatments ${ }^{\mathrm{z}}$ & $\begin{array}{c}\text { Yield } \\
\text { (kg/vine) }\end{array}$ & $\begin{array}{l}\text { Number of } \\
\text { clusters/vine }\end{array}$ & Cluster wt (g) & $\begin{array}{l}\text { Berries per } \\
\text { cluster }\end{array}$ & Berry wt (g) & $\begin{array}{l}\text { Percent rot berries } \\
\text { per cluster }\end{array}$ \\
\hline \multicolumn{7}{|c|}{ Defoliation (D) } \\
\hline CUD & 4.9 & 51 & $108 a^{x}$ & 78 & $1.39 \mathrm{a}$ & $5.7 \mathrm{a}$ \\
\hline 33D & 5.2 & 54 & $102 \mathrm{ab}$ & 76 & $1.36 \mathrm{ab}$ & $2.2 \mathrm{~b}$ \\
\hline 66D & 4.7 & 48 & $99 \mathrm{~b}$ & 75 & $1.30 \mathrm{~b}$ & $2.0 \mathrm{~b}$ \\
\hline \multicolumn{7}{|l|}{ Nitrogen $(\mathrm{N})$} \\
\hline $\mathrm{TN}$ & 4.8 & 48 & 104 & 78 & 1.39 & 1.9 \\
\hline $\mathrm{CN}$ & 5.0 & 52 & 103 & 76 & 1.36 & 2.0 \\
\hline \multicolumn{7}{|l|}{ Significance ${ }^{w}$} \\
\hline $\mathrm{D}$ & $\mathrm{NS}^{\mathrm{y}}$ & NS & * & NS & ** & $* * *$ \\
\hline $\mathrm{N}$ & NS & NS & NS & NS & NS & NS \\
\hline $\mathrm{D} \times \mathrm{N}$ & NS & NS & NS & NS & NS & NS \\
\hline
\end{tabular}

${ }^{2}$ Defoliation CUD, 33D, 66D indicate treatments in which 0, one-third, or two-thirds of leaves were removed at veraison, respectively. TN indicates a $1 \%$ urea solution was sprayed at veraison; $\mathrm{CN}$ indicates no urea was applied.

${ }^{y}$ Statistical analysis was performed on log-transformed data. Values in the table are original mean values. ${ }^{x}$ Means in a column followed by the same letter are not significantly different at $P \leq 0.05$ by least significant difference test.

${ }^{\text {wResult of analysis of variance: }{ }^{*}, * *, * * *}$ and Ns indicate significance at $P \leq 0.05,0.01,0.001$, and nonsignificant, respectively.

Table 3. Impact of defoliation and foliar nitrogen application on grape must chemical parameters and shoot fruit load related parameters.

\begin{tabular}{|c|c|c|c|c|c|c|c|}
\hline Treatments $^{\mathrm{z}}$ & SS $(\%)^{y}$ & $\mathrm{pH}$ & TA $\left(g \cdot L^{-1}\right)^{y}$ & $\begin{array}{l}\text { Total volatile } \\
\text { terpenes } \\
\left(\mathrm{mg} \cdot \mathrm{L}^{-1}\right)\end{array}$ & $\begin{array}{c}\text { Total sugar } \\
\text { (g)/shoot }\end{array}$ & $\begin{array}{l}\mathrm{LA}\left(\mathrm{cm}^{2}\right) \text { to } \\
\text { fruit }(\mathrm{g}) \text { ratio }^{\mathrm{x}}\end{array}$ & $\begin{array}{c}\text { Yeast available } \\
\text { amino-N } \\
\left(\mathrm{mg} \cdot \mathrm{L}^{-1}\right)\end{array}$ \\
\hline \multicolumn{8}{|c|}{ Defoliation (D) } \\
\hline CUD & $22.1 \mathrm{a}$ & $3.45^{\mathrm{w}}$ & 6.78 & 0.98 & $33.9 \mathrm{a}$ & $25.2 \mathrm{a}$ & 192 \\
\hline 33D & $21.1 \mathrm{~b}$ & 3.45 & 7.09 & 1.05 & $30.6 \mathrm{ab}$ & $17.2 \mathrm{~b}$ & 186 \\
\hline $66 \mathrm{D}$ & $20.8 \mathrm{~b}$ & 3.44 & 6.60 & 1.00 & $28.3 \mathrm{~b}$ & $7.1 \mathrm{c}$ & 182 \\
\hline \multicolumn{8}{|l|}{ Nitrogen $(\mathrm{N})$} \\
\hline TN & 21.2 & 3.5 & 6.89 & 1.02 & 30.9 & 16.2 & $203 \mathrm{a}$ \\
\hline $\mathrm{CN}$ & 21.3 & 3.4 & 6.74 & 1.00 & 30.6 & 16.9 & $170 \mathrm{~b}$ \\
\hline \multicolumn{8}{|l|}{ Significance $^{v}$} \\
\hline $\mathrm{D}$ & ** & NS & NS & NS & ** & $* * *$ & NS \\
\hline $\mathrm{N}$ & NS & NS & NS & NS & NS & NS & $*$ \\
\hline $\mathrm{D} \times \mathrm{N}$ & NS & NS & NS & NS & NS & NS & NS \\
\hline
\end{tabular}

${ }^{\mathrm{z} D e f o l i a t i o n}$ CUD, 33D, 66D indicate treatments in which 0, one-third, or two-thirds of leaves were removed at veraison, respectively. $\mathrm{TN}$ indicates a $1 \%$ urea solution was sprayed at veraison; $\mathrm{CN}$ indicates no urea was applied.

${ }^{y} \mathrm{SS}(\%)$ and TA represent percent soluble solids and titratable acidity, respectively.

${ }^{\times}$Ratio between shoot leaf area (LA) at veraison and shoot yield at harvest.

wMeans in a column followed by the same letter are not significantly different at $P \leq 0.05$ by least significant difference test.

${ }^{v}$ Result of analysis of variance: $* * *, * * *$ and Ns indicate significance at $P \leq 0.05,0.01,0.001$, and nonsignificant, respectively. 
amino-N in the juice, increased in TN (Table 3 ). Reduction of LA also corresponded to a slight trend in decreasing berry $\mathrm{N}$ content, but differences observed were not statistically significant.

Shoot and leaf photosynthetic rate. Shoot photosynthesis, estimated by the mean $\mathrm{P}_{\mathrm{n}}$ of leaves at three different positions on the shoot (nodes 4 and 5, nodes 10 through 15, and apical nodes with fully expanded leaves), was unaffected by the two main factors of the experiment and it was rather uniform at the three times of measurement (Table 4). However, leaf position interacted with treatments. Fruiting zone leaves (nodes 4 and 5) were not directly affected by single factors after $8 \mathrm{~d}$ post-treatment application, but an initial reduction in leaf $P_{n}$ was observed in vines severely defoliated and sprayed with $\mathrm{N}(66 \mathrm{D}+$ TN). $P_{n}$ of these leaves was decreased in $33 \mathrm{D}$ and $66 \mathrm{D}$ compared with the CUD in the second and third week after veraison; moreover, $\mathrm{P}_{\mathrm{n}}$ was reduced by $\mathrm{N}$ application at the third week and in 33D + TN starting from the second week (Table 4). For basal leaves, a significant decrease in $\mathrm{F}_{\mathrm{v}} / \mathrm{F}_{\mathrm{m}}$ (Table 5) was observed after defoliation as early as 1 week after treatment applications, thus before the observed decrease in $\mathrm{P}_{\mathrm{n}}$. A chlorophyll degradation process in basal leaves was also evident in the 33D and 66D treatments $22 \mathrm{~d}$ after the defoliation, as seen in the reduced chlorophyll content (SPAD index) measured on these leaves (Table 5). The response of more recently developed leaves was different from basal leaves; $8 \mathrm{~d}$ and $15 \mathrm{~d}$ after treatment application, the $\mathrm{P}_{\mathrm{n}}$ rate of those leaves in 33D and 66D was higher than the CUD (Table 4). Interestingly, for these younger leaves (apical node), the effect of $\mathrm{N}$ application interacted with the defoliation factor at least in the first week after veraison. Leaves of 33D + TN and 66D + TN vines had the highest $\mathrm{P}_{\mathrm{n}}$, particularly when compared with leaves from CUD + TN vines. The interaction between the two effects, defoliation and $\mathrm{N}$ application, was not significant at 2 weeks after veraison and the resulting $P_{n}$ of apical leaves supplied with $\mathrm{N}$ was, overall, higher than the $\mathrm{CN}$ leaves at a similar position. Even so, this effect disappeared 3 weeks after the urea application at which time a higher value of $F_{v} / F_{m}$ in the N-sprayed leaves was observed. Photochemical efficiency and chlorophyll content in these leaves were otherwise unchanged by either factor after veraison.

\section{Discussion}

The most relevant effects of defoliation on yield components were the reductions in berry and cluster growth and the lower accumulation of sugars in the berries with the highest level of defoliation (66D) producing the greatest impact (Tables 2 and 3). Similarly, in previous studies, severe defoliation was associated with a delay in the ripening process (Candolfi-Vasconcelos et al., 1994b; Petrie et al., 2000a), but not with a reduction in berry weight when defoliation was performed after veraison. Differently, Hunter et al.

Table 4. Net assimilation rate $\left(\mathrm{P}_{\mathrm{n}}\right)$ measured at midday (1100 HR to $\left.1300 \mathrm{HR}\right), 8,15$ and $22 \mathrm{~d}$ after applied treatments on leaves at different node positions counted from the base of the shoot (node 4 to 5 and apical node with fully expanded leaves) and mean of shoot assimilation rate (mean of measurements performed on node 4 to 5 , node 10 to 15 , and apical node with fully expanded leaves).

\begin{tabular}{|c|c|c|c|c|c|c|c|c|c|}
\hline \multirow[b]{3}{*}{ Treatments $^{z}$} & \multicolumn{9}{|c|}{ Net assimilation rate $\left(\mu \mathrm{mol} \mathrm{CO}_{2} \cdot \mathrm{m}^{-2} \cdot \mathrm{s}^{-1}\right)$} \\
\hline & \multicolumn{3}{|c|}{ Node 4 to 5} & \multicolumn{3}{|c|}{ Apical node ${ }^{w}$} & \multicolumn{3}{|c|}{ Shoot mean } \\
\hline & $8 \mathrm{~d}$ & $15 \mathrm{~d}$ & $22 \mathrm{~d}$ & $8 \mathrm{~d}$ & $15 \mathrm{~d}$ & $22 \mathrm{~d}$ & $8 \mathrm{~d}$ & $15 \mathrm{~d}$ & $22 \mathrm{~d}$ \\
\hline \multicolumn{10}{|l|}{$\overline{\text { Defoliation (D) }}$} \\
\hline CUD & 11.3 & $12.2 \mathrm{a}^{\mathrm{x}}$ & $11.0 \mathrm{a}$ & $12.2 \mathrm{~b}$ & $12.0 \mathrm{~b}$ & $12.1 \mathrm{~b}$ & 11.7 & 12.0 & 11.7 \\
\hline $33 \mathrm{D}$ & 11.0 & $10.6 \mathrm{~b}$ & $10.1 \mathrm{ab}$ & $12.9 \mathrm{a}$ & $13.4 \mathrm{a}$ & $13.4 \mathrm{a}$ & 11.9 & 12.3 & 12.0 \\
\hline $66 \mathrm{D}$ & 10.6 & $10.3 \mathrm{~b}$ & $9.7 \mathrm{~b}$ & $13.2 \mathrm{a}$ & $12.9 \mathrm{a}$ & $12.5 \mathrm{~b}$ & 12.0 & 11.7 & 11.4 \\
\hline \multicolumn{10}{|l|}{ Nitrogen $(\mathrm{N})$} \\
\hline $\mathrm{TN}$ & 10.8 & $10.7 \mathrm{~b}$ & $9.8 \mathrm{~b}$ & 12.9 & $13.1 \mathrm{a}$ & 12.8 & 11.9 & 12.0 & 11.6 \\
\hline $\mathrm{CN}$ & 11.1 & $11.3 \mathrm{a}$ & $10.7 \mathrm{a}$ & 12.6 & $12.4 \mathrm{~b}$ & 12.5 & 11.9 & 12.0 & 11.8 \\
\hline \multicolumn{10}{|c|}{ Interaction $(\mathrm{D} \times \mathrm{N})$} \\
\hline $\mathrm{CUD}+\mathrm{CN}$ & $11.1 \mathrm{ab}$ & $12.4 \mathrm{a}$ & 11.3 & $12.3 \mathrm{ab}$ & 11.5 & 12.0 & 11.7 & 11.9 & 11.7 \\
\hline CUD + TN & $11.4 \mathrm{a}$ & $11.9 \mathrm{ab}$ & 10.7 & $12.0 \mathrm{~b}$ & 12.4 & 12.2 & 11.6 & 12.1 & 11.6 \\
\hline $33 \mathrm{D}+\mathrm{CN}$ & $10.9 \mathrm{ab}$ & $11.3 \mathrm{~b}$ & 10.6 & $12.5 \mathrm{ab}$ & 13.1 & 13.3 & 11.7 & 12.4 & 12.1 \\
\hline $33 \mathrm{D}+\mathrm{TN}$ & $11.1 \mathrm{ab}$ & $9.8 \mathrm{c}$ & 9.5 & $13.2 \mathrm{a}$ & 13.7 & 13.5 & 12.1 & 12.2 & 11.9 \\
\hline $66 \mathrm{D}+\mathrm{CN}$ & $11.4 \mathrm{a}$ & $10.2 \mathrm{bc}$ & 10.1 & $12.9 \mathrm{ab}$ & 12.7 & 12.3 & 12.1 & 11.7 & 11.5 \\
\hline $66 \mathrm{D}+\mathrm{TN}$ & $9.8 \mathrm{~b}$ & $10.4 \mathrm{bc}$ & 9.3 & $13.5 \mathrm{a}$ & 13.1 & 12.7 & 11.9 & 11.8 & 11.4 \\
\hline \multicolumn{10}{|l|}{ Significance } \\
\hline D & $\mathrm{NS}^{\mathrm{y}}$ & $* *$ & $*$ & $* *$ & ** & $* * *$ & NS & NS & NS \\
\hline $\mathrm{N}$ & NS & $*$ & $*$ & NS & $* *$ & NS & NS & NS & NS \\
\hline $\mathrm{D} \times \mathrm{N}$ & $*$ & $* *$ & NS & $* *$ & NS & NS & NS & NS & NS \\
\hline
\end{tabular}

${ }^{\mathrm{z}}$ Defoliation CUD, 33D, 66D indicate treatments in which 0, one-third, or two-thirds of leaves were removed at veraison, respectively. $\mathrm{TN}$ indicates a $1 \%$ urea solution was sprayed at veraison; $\mathrm{CN}$ indicates no urea was applied.

${ }^{y}$ Result of analysis of variance: ${ }^{* * *},{ }^{* * *}$ and NS indicate significance at $P \leq 0.05,0.01,0.001$, and nonsignificant, respectively.

${ }^{\mathrm{x}}$ Means in a column followed by the same letter are not significantly different at $P \leq 0.05$ by least significant difference test.

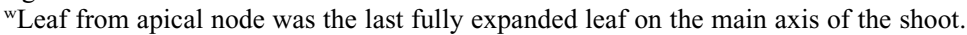

Table 5. SPAD and maximum photochemical efficiency of PSII $\left(\mathrm{F}_{\mathrm{v}} / \mathrm{F}_{\mathrm{m}}\right)$ measured on leaves positioned at different node positions counted from the base of the shoot (node 4 to 5 and apical node with fully expanded leaves) 8 and $22 \mathrm{~d}$ from the time of application of the treatments.

\begin{tabular}{|c|c|c|c|c|c|c|c|c|}
\hline \multirow[b]{3}{*}{ Treatments $^{\mathrm{z}}$} & \multicolumn{4}{|c|}{$\mathrm{F}_{\mathrm{v}} / \mathrm{F}_{\mathrm{m}}$ (arbitrary units) } & \multicolumn{4}{|c|}{ SPAD index } \\
\hline & \multicolumn{2}{|c|}{ Node 4 to 5} & \multicolumn{2}{|c|}{ Apical node ${ }^{y}$} & \multicolumn{2}{|c|}{ Node 4 to 5} & \multicolumn{2}{|c|}{ Apical node } \\
\hline & $8 \mathrm{~d}$ & $22 \mathrm{~d}$ & $8 \mathrm{~d}$ & $22 \mathrm{~d}$ & $8 \mathrm{~d}$ & $22 \mathrm{~d}$ & $8 \mathrm{~d}$ & $22 \mathrm{~d}$ \\
\hline \multicolumn{9}{|l|}{$\overline{\text { Defoliation (D) }}$} \\
\hline CUD & $0.789 \mathrm{a}^{\mathrm{x}}$ & $0.726 \mathrm{a}$ & 0.791 & 0.768 & $39.4 \mathrm{a}$ & $34.0 \mathrm{a}$ & 36.9 & 36.7 \\
\hline $33 \mathrm{D}$ & $0.750 \mathrm{~b}$ & $0.653 \mathrm{~b}$ & 0.796 & 0.782 & $38.8 \mathrm{a}$ & $29.6 \mathrm{~b}$ & 40.0 & 38.4 \\
\hline $66 \mathrm{D}$ & $0.752 \mathrm{~b}$ & $0.658 \mathrm{~b}$ & 0.786 & 0.786 & $34.7 \mathrm{~b}$ & $26.0 \mathrm{c}$ & 37.2 & 37.5 \\
\hline \multicolumn{9}{|l|}{ Nitrogen $(\mathrm{N})$} \\
\hline Nitrogen & 0.762 & $0.663 \mathrm{~b}$ & 0.795 & $0.793 \mathrm{a}$ & 38.1 & 29.5 & 39.2 & 37.7 \\
\hline Control & 0.766 & $0.695 \mathrm{a}$ & 0.786 & $0.764 \mathrm{~b}$ & 37.2 & 30.2 & 36.8 & 37.3 \\
\hline \multicolumn{9}{|c|}{ Interaction $(\mathrm{D} \times \mathrm{N})$} \\
\hline $\mathrm{CUD}+\mathrm{CN}$ & 0.791 & 0.731 & 0.785 & 0.755 & 39.6 & 33.4 & 35.6 & 36.1 \\
\hline $\mathrm{CUD}+\mathrm{TN}$ & 0.787 & 0.720 & 0.796 & 0.780 & 39.2 & 34.5 & 38.2 & 37.3 \\
\hline $33 \mathrm{D}+\mathrm{CN}$ & 0.749 & 0.674 & 0.788 & 0.773 & 38.2 & 29.2 & 39.0 & 38.9 \\
\hline $33 \mathrm{D}+\mathrm{TN}$ & 0.752 & 0.633 & 0.803 & 0.791 & 39.4 & 30.0 & 40.9 & 37.9 \\
\hline $66 \mathrm{D}+\mathrm{CN}$ & 0.758 & 0.680 & 0.786 & 0.774 & 33.7 & 27.9 & 35.9 & 36.9 \\
\hline $66 \mathrm{D}+\mathrm{TN}$ & 0.746 & 0.637 & 0.785 & 0.798 & 35.7 & 24.1 & 38.4 & 38 \\
\hline \multicolumn{9}{|l|}{ Significance $^{\mathrm{w}}$} \\
\hline $\mathrm{D}$ & $*$ & $* *$ & NS & NS & * & $*$ & NS & NS \\
\hline $\mathrm{N}$ & NS & $*$ & NS & $*$ & NS & NS & NS & NS \\
\hline $\mathrm{D} \times \mathrm{N}$ & NS & NS & NS & NS & NS & NS & NS & NS \\
\hline
\end{tabular}

${ }^{z}$ Defoliation CUD, 33D, 66D indicate treatments in which 0, one-third, or two-thirds of leaves were removed at veraison, respectively. TN indicates a $1 \%$ urea solution was sprayed at veraison; $\mathrm{CN}$ indicates no urea was applied.

${ }^{y}$ Leaf from apical node was the last fully expanded leaf on the main axis of the shoot.

${ }^{x}$ Means in a column followed by the same letter are not significantly different at $P \leq 0.05$ by least significant difference test.

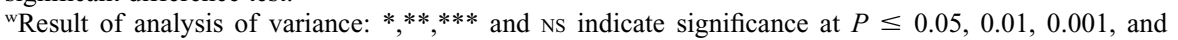
nonsignificant, respectively.

(1991) observed an improvement in fruit composition of 'Cabernet Sauvignon' grapes after vine defoliation at veraison, but not an impact on berry volume. In contrast, in our experiment, a reduction of berry weight and juice sugar content was observed at harvest in
$33 \mathrm{D}$ and 66D vines, especially when compared with CUD vines. This result cannot be attributed solely to source availability or $P_{n}$. Indeed, the reduction in both cluster weight $(9 \%)$ and mean berry weight $(7 \%)$ in $66 \mathrm{D}$ did not proportionally reflect the decrease in LA. 
This suggests that a compensation mechanism may have been activated in response to the reduced source of photosynthates. In grapevine, an increase in canopy productivity (Candolfi-Vasconcelos and Koblet, 1991; Edson et al., 1993), a modification in allocation of current photosynthates (Edson et al., 1993; Petrie et al., 2000a), a remobilization of stored reserves (Candolfi-Vasconcelos et al., 1994a), or a combination of these different processes could be responsible for this compensation. Compensatory responses to defoliation are reported in the literature for leaf removal in the earliest phenological stages of vine development (Poni et al., 2008) with recently fully expanded leaves. This was confirmed in our experiment in which apical leaf $\mathrm{P}_{\mathrm{n}}$ and efficiency are positively responsive to both defoliation and $\mathrm{N}$ supply. However, we did not observe the compensation effect on basal leaf $\mathrm{P}_{\mathrm{n}}$ observed by other authors (Candolfi-Vasconcelos et al., 1994b; Petrie et al., 2003). Moreover, we

Table 6. Correlations among juice composition (percent soluble solids, \%SS; yeast available amino-nitrogen, Amino-N) and shoot source sink parameters (leaf area, LA; and leaf areato-fruit ratio, Fruit/LA).

\begin{tabular}{|c|c|c|c|}
\hline \multirow[b]{2}{*}{ Variables } & \multicolumn{2}{|c|}{ Nitrogen application } & \multirow{2}{*}{$\begin{array}{l}\text { Combined } \\
\text { treatments }\end{array}$} \\
\hline & TN & $\mathrm{CN}^{\mathrm{z}}$ & \\
\hline $\begin{array}{l}\text { Amino-N vs. } \\
\% \mathrm{SS}\end{array}$ & $0.055^{y} \mathrm{NS}^{\mathrm{x}}$ & $0.058 \mathrm{NS}$ & $0.006 \mathrm{NS}$ \\
\hline $\begin{array}{l}\text { Amino-N vs. } \\
\text { LA }\end{array}$ & $0.277 * * *$ & $0.104 \mathrm{NS}$ & $0.120 *$ \\
\hline $\begin{array}{l}\text { Amino-N vs. } \\
\text { Fruit/LA }\end{array}$ & $0.141 \mathrm{NS}$ & $-0.003 \mathrm{NS}$ & $0.074 \mathrm{NS}$ \\
\hline $\begin{array}{l}\text { \%SS vs. } \\
\text { leaf area }\end{array}$ & $0.179 *$ & $0.237 * *$ & $0.205^{* * *}$ \\
\hline $\begin{array}{l}\% \text { SS vs. } \\
\text { Fruit/LA }\end{array}$ & $0.393 * * *$ & $0.362 * * *$ & $0.377 * * *$ \\
\hline
\end{tabular}

${ }_{\text {zTN indicates a } 1 \% \text { urea solution was sprayed at }}$ veraison; $\mathrm{CN}$ indicates no urea was applied.

yPearson's correlation coefficient $(r)$.

${ }^{\mathrm{x}}$ Coefficient significance: $*, * *, * * *$ and Ns indicate significance at $P \leq 0.05,0.01,0.001$, and nonsignificant, respectively. estimated no net gain in $\mathrm{P}_{\mathrm{n}}$ at the shoot level when performing the defoliation at veraison. In fact, we recorded a reduction in $\mathrm{P}_{\mathrm{n}}$ on basal leaves, particularly under $66 \mathrm{D}$ treatment (Table 4). We speculate that shaded basal leaves were negatively affected by the sudden high sunlight exposure caused by the treatment. The described effect of treatments on basal leaf photochemical efficiency $\left(\mathrm{F}_{\mathrm{v}} /\right.$ $F_{m}$ ) and chlorophyll degradation is consistent with this type of damage (Table 5). It occurred right after the defoliation treatment, preceding the reduction in leaf $\mathrm{P}_{\mathrm{n}}$. However, when LA-to-fruit ratio was calculated for the three defoliation treatments (Table 3), the data showed a reduction of $32 \%$ and $72 \%$ from CUD, in 33D and 66D, respectively. Although dramatically reduced, the LA-tofruit ratio calculated for $66 \mathrm{D}\left(7.1 \mathrm{~cm}^{2}\right.$ of leaf area per gram of fruit) still falls in the optimal range ( 7 to 14 ) to achieve fruit ripening in wine grape varieties suggested by Dokoozlian and Hirschfelt (1995). LA-to-fruit ratio for the 33D and CUD vines is well above that optimal range.

Berry $\mathrm{N}$ content is dependent on vine $\mathrm{N}$ status (Bell and Henschke, 2008) and, although it has been previously shown that application of soil $\mathrm{N}$ is generally effective in increasing YAN and total $\mathrm{N}$ in the berries (Spayd et al., 1995, 2000), the effect of foliar sprays on the accumulation of $\mathrm{N}$ during the ripening phase has been less extensively studied at least in cool climate conditions (Cheng and Martinson, 2009), whereas some positive results have been obtained in warmer climate (Lasa et al., 2012). According to our results, berry $\mathrm{N}$ was increased in all vines sprayed with urea (Table 3), suggesting that increased leaf $\mathrm{N}$ through the foliar application could have triggered its translocation to the berries. If the translocation to clusters was proportional to the amount of $\mathrm{N}$ applied on the vine, we would have observed differences in yeast available amino- $\mathrm{N}$ according to the three levels of defoliation imposed, because

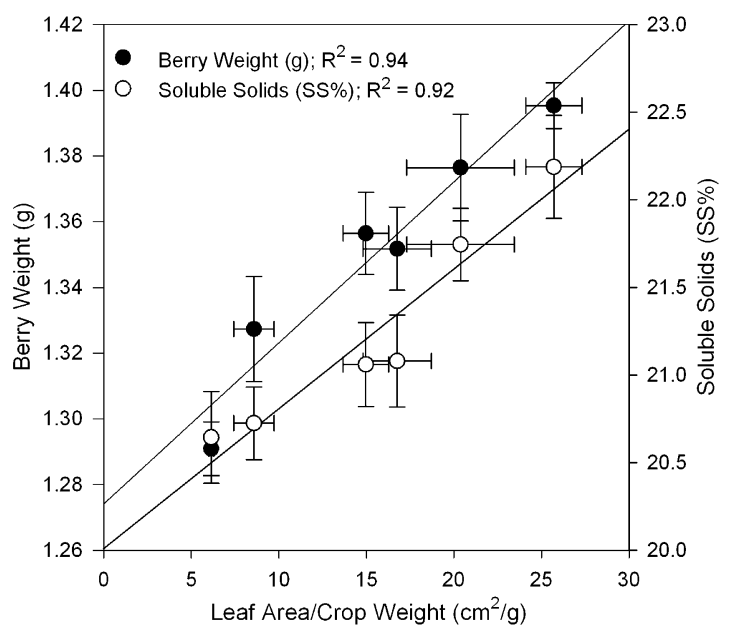

Fig. 2. Linear regression between shoot leaf area $\left(\mathrm{cm}^{2}\right)$ at veraison-to-crop $(\mathrm{g})$ ratio at harvest and mean berry weight $(\mathrm{g})$ and soluble solids $(\% \mathrm{SS})$ at harvest. Each point represents the mean $(\mathrm{n}=45)$ of all shoots at each level of defoliation (CUD, 33D, and 66D) with or without nitrogen application (TN and $\mathrm{CN})$. Bars represent SE.

more urea was applied in non-defoliated vines. Instead, the differences observed are not statistically significant and shoot LA was not highly correlated with berry amino-N (Table 6). However, when correlation analysis was conducted separating the two $\mathrm{N}$ treatment levels, $\mathrm{TN}$ and $\mathrm{CN}$, a higher, although still small, correlation between the mean shoot LA and the $\mathrm{N}$ content of the berries (indexed as yeast available amino-N) was found. A similar positive correlation was observed also between \%SS and LA, and this was consistent with the reduced sugar accumulation observed in the berries of highly defoliated vines (66D). Percent SS and amino-N were not correlated; consistent with that, the reduced sugar accumulation did not correspond to an equal reduction in free amino acids in the berries. Therefore, translocation of $\mathrm{N}$ from the leaves after veraison seems not only independent from the total source available, but also to be distinguished from the accumulation of other solutes in the berries, mainly sugars. Sugar accumulation is more influenced by the LA/ fruit ratio, as seen in a higher correlation coefficient (Table 6), therefore more dependent on the source sink ratio manipulated through the defoliation rather than by the sole source availability (Fig. 2). The same trend is also observed for berry weight, which is consistently higher when LA-to-crop weight ratio is increased (Fig. 2).

\section{Conclusions}

$\mathrm{N}$ application at veraison did not affect canopy efficiency nor reduce leaf aging. We simulated the effect of a reduced available source for fruit ripening and showed that the increased $\mathrm{N}$ availability was effective only on younger leaves in which an increase of leaf $\mathrm{P}_{\mathrm{n}}$ was observed. This was consistent with an increase of chlorophyll content. Fruit growth and ripening, as indicated by $\% \mathrm{SS}$, were impaired by the removal of two-thirds of the leaves, although not proportionally to source reduction, indicating that either a different allocation pattern or the remobilization of stored reserves could have compensated for the reduction in leaf assimilated sugars. Although foliar $\mathrm{N}$ did not affect yield components, leaf or shoot $P_{n}$, or shoot growth, it was highly effective in increasing amino-N content of berries. This increase can be explained by an increased translocation of $\mathrm{N}$ in the cluster. Additionally, only a small correlation with total leaf area or sugar content of the berries was found, although $\mathrm{N}$ applied after veraison may reduce problems of low levels of YAN in the juice. The $\mathrm{N}$ foliar application effect may be variable according to the climatic conditions, as reflected in the variability of fruit composition, also cultivardependent, that can be achieved in the different vintages in cool climate regions. All defoliation treatments (from $0 \%$ to $66 \%$ of leaves removed at veraison) were within or higher than the suggested 7 to $14 \mathrm{LA}\left(\mathrm{cm}^{2}\right)$ to crop $(\mathrm{g})$ ratio. However, the $66 \mathrm{D}$ treatment (7.1 LA cm$~^{2} \cdot \mathrm{g}^{-1}$ of fruit) resulted in a significant 
decrease of berry weight and \%SS indicating that 'Chardonnay' grapevines in cool climate conditions may require a LA-to-fruit ratio at the high end of the range suggested by the literature.

\section{Literature Cited}

Baskerville, G.L. and P. Emin. 1969. Rapid estimation of heat accumulation from maximum and minimum temperatures. Ecology 50:514 517.

Bates, T.R. and T.K. Wolf. 2008. Vineyard nutrient management, p. 141-168. In: Wolf, T.K. (ed.). Wine grape production guide for eastern North America. Natural Resource, Agr. Eng. Serv. Coop. Ext., Ithaca, NY.

Bell, S.J. and P.A. Henschke. 2008. Implications of nitrogen nutrition for grapes, fermentation and wine. Austral. J. Grape Wine Res. 11:242-295.

Candolfi-Vasconcelos, M.C., M.P. Candolfi, and W. Koblet. 1994a. Retranslocation of carbon reserves from the woody storage tissues into the fruit as a response to defoliation stress during the ripening period in Vitis vinifera L. Planta 192:567-573.

Candolfi-Vasconcelos, M.C., W. Koblet, G.S Howell, and W. Zweifel. 1994b. Influence of defoliation, rootstock, training system, and leaf position on gas exchange of Pinot noir grapevines. Amer. J. Enol. Viticult. 45:173-180.

Candolfi-Vasconcelos, M.C. and W. Koblet. 1991. Influence of partial defoliation on gas exchange parameters and chlorophyll content of fieldgrown grapevines: Mechanisms and limitations of the compensation capacity. Vitis 30:129 141.

Cheng, L. and T. Martinson. 2009. The effect of foliar nitrogen application on juice yeast available nitrogen in 'Riesling' depends on vine nitrogen status. HortScience 44:1060 (abstr.).

Conradie, W.J. 1990. Distribution and translocation of nitrogen absorbed during late spring by two-year-old grapevines grown in sand culture. Amer. J. Enol. Viticult. 41:241-250.

Dokoozlian, N. and D.J. Hirschfelt. 1995. The influence of cluster thinning at various stages of fruit development on Flame seedless table grapes. Amer. J. Enol. Viticult. 46:429-436.

Dukes, B.C. and C.E. Butzke. 1998. Rapid determination of primary amino acids in grape juice using an o-phthaldialdehyde/n-acetyl-1-cysteine spectrophotometric assay. Amer. J. Enol. Viticult. 49:125-134.

Edson, C.E., G.S. Howell, and J.A. Flore. 1993. Influence of crop load on photosynthesis and dry matter partitioning of Seyval grapevines. I. Single leaf and whole vine response pre-and post-harvest. Amer. J. Enol. Viticult. 44:139147.

Eichhorn, K.W. and D.H. Lorenz. 1977. Phöenologische Entwicklungsstadie. Der rebe. Nachrichtenb. Deutsch Pflanzenschutzd (Braunschweig) 29: 119-120.

Howell, G.S. and P. Sabbatini. 2008. Achieving vine balance with variable annual weather conditions. Proc. Midwest Grape Wine Conf., MO. p. 93-103.

Hunter, J.J., O.T. De Villiers, and J.E. Watts. 1991. The effect of partial defoliation on quality characteristics of Vitis vinifera L. cv. Cabernet Sauvignon grapes. II. Skin color, skin sugar, and wine quality. Amer. J. Enol. Viticult. 42:13-18.

Hunter, J.J. and J.H. Visser. 1988. The effect of partial defoliation, leaf position and developmental stage of the vine on the photosynthetic activity of Vitis vinifera L. cv. Cabernet Sauvignon. S. Afr. J. Enol. Vitic. 9:9-15.

Iland, P., N. Bruer, G. Edwards, S. Weeks, and E. Wilkes. 2004. Chemical analysis of grapes and wine: Techniques and concepts. Patrick Iland Wine Promotions Pty. Ltd., Adelaide, Australia.

Jackson, D.I. and P.B. Lombard. 1993. Environmental and management practices affecting grape composition and wine quality-A review. Amer. J. Enol. Viticult. 44:409-430.

Keller, M. 2005. Deficit irrigation and vine mineral nutrition. Amer. J. Enol. Viticult. 56:267-283.

Keller, M. 2010. The science of grapevines: Anatomy and physiology. Academic Press/Elsevier, New York, NY.

Kliewer, W.M. 1968. Changes in the concentration of free amino acids in grape berries during maturation. Amer. J. Enol. Viticult. 19:166174.

Kriedemann, P.E. 1968. Photosynthesis in vine leaves as a function of light intensity, temperature, and leaf age. Vitis 7:213-220.

Lasa, B., S. Menendez, K. Sagastizabal, M.E. Calleja Cervantes, I. Irigoyen, J. Muro, P.M Aparicio-Tejo, and I. Ariz. 2012. Foliar application of urea to 'Sauvignon Blanc' and 'Merlot' vines: doses and time of application. Plant Growth Regulat. 67:73-81.

Löhnertz, O., B. Prior, M. Bleser, and A. Linsenmeier. 1998. Influence of N-supply and soil management on the nitrogen composition of grapes. Acta Hort. 512:55-64.

Palliotti, A., M. Gatti, and S. Poni. 2011. Early leaf removal to improve vineyard efficiency: Gas exchange, source-to-sink balance, and reserve storage responses. Amer. J. Enol. Viticult. 62 : 219-228.

Petrie, P.R., M.C.T. Trought, and G.S. Howell. 2000a. Growth and dry matter partitioning of
Pinot noir (Vitis vinifera L.) in relation to leaf area and crop load. Austral. J. Grape Wine Res. 6:40-45.

Petrie, P.R., M.C.T. Trought, and G.S. Howell. 2000b. Influence of leaf ageing, leaf area and crop load on photosynthesis, stomatal conductance and senescence of grapevine (Vitis vinifera $\mathrm{L}$. cv. Pinot noir) leaves. Vitis 39: 31-36.

Petrie, P.R., M.C.T. Trought, G.S. Howell, and G.D. Buchan. 2003. The effect of leaf removal and canopy height on whole-vine gas exchange and fruit development of Vitis vinifera $\mathrm{L}$. Sauvignon blanc. Funct. Plant Biol. 30:711717.

Poni, S., F. Bernizzoni, and S. Civardi. 2008. The effect of early leaf removal on whole-canopy gas exchange and vine performance of Vitis vinifera $\mathrm{L}$. 'Sangiovese'. Vitis 47:1-6.

Poni, S., C. Intrieri, and O. Silvestroni. 1994. Interactions of leaf age, fruiting, and exogenous cytokinins in Sangiovese grapevines under nonirrigated conditions. I. Gas exchange. Amer. J. Enol. Viticult. 45:71-78.

Porro, D., A. Ceschini, C. Dorigatti, and M. Stefanini. 2001. Use of SPAD meter in diagnosis of nutritional status in apple and grapevine. Acta Hort. 564:243-252.

Rodriguez-Lovelle, B. and J.P. Gaudillère. 2002 Carbon and nitrogen partitioning in either fruiting or non-fruiting grapevines: Effects of nitrogen limitation before and after veraison. Austral. J. Grape Wine Res. 8:86-94.

Spayd, S.E., C.W. Nagel, and C.G. Edwards. 1995 Yeast growth in Riesling juice as affected by vineyard nitrogen fertilization. Amer. J. Enol. Viticult. 46:49-55.

Spayd, S.E., R.G. Stevens, R.L. Wample, R.G. Evans, C.G. Edwards, and D. Webster. 2000. Impact of nitrogen fertilization on vine performance and juice and wine composition of 'Riesling' grapes (Vitis vinifera L.) in Washington State. Acta Hort. 512:65-76.

U.S. Department of Agriculture, Soil Conservation Service. 1957. Major soils of the north central region, U.S.A. Map. Soil Survey, North Central Regional Publication 76. Government Printing Office, Washington, DC.

Wise, J.C., L.J. Gut, R. Isaacs, A.M.C. Schilder, G.W. Sundin, B. Zandstra, R. Beaudry, and G. Lang. 2008. Michigan fruit management guide. Mich. State Univ. Ext. Bull. E-154.

Zoecklein, B.W., T.K. Wolf, N.W. Duncan, J.M. Judge, and M.K. Cook. 1992. Effects of fruit zone leaf removal on yield, fruit composition, and fruit rot incidence of Chardonnay and White Riesling (Vitis vinifera L.) grapes. Amer. J. Enol. Viticult. 43:139-148. 